Research Report No. 46/2010

\title{
A Critical Legal Pluralist Analysis of the Begum Case
}

Amy Jackson

Follow this and additional works at: http:/ / digitalcommons.osgoode.yorku.ca/clpe

\section{Recommended Citation}

Jackson, Amy, "A Critical Legal Pluralist Analysis of the Begum Case" (2010). Comparative Research in Law \& Political Economy. Research Paper No. 46/2010.

http://digitalcommons.osgoode.yorku.ca/clpe/112 


\section{OSGOODE}

OSCOODE HALL LAW SCHOOL

YOR K UNIVERSITY

\section{OSGOODE HALL LAW SCHOOL}

Comparative Research in Law \& Political Economy

RESEARCH PAPER SERIES

Research Paper No. 46/2010

\section{A Critical Legal Pluralist Analysis of the Begum Case}

Amy Jackson

\section{Editors:}

Peer Zumbansen (Osgoode Hall Law School, Toronto, Director, Comparative Research in Law and Political Economy)

John W. Cioffi (University of California at Riverside)

Lisa Philipps (Osgoode Hall Law School, Associate Dean Research)

Nassim Nasser (Osgoode Hall Law School, Toronto,

Production Editor) 
Osgoode CLPE Research Paper 46/2010

Vol. 06 No. 10 (2010)

\title{
Amy Jackson
}

\section{A Critical Legal Pluralist Analysis of the Begum Case}

\begin{abstract}
This paper considers the advantages of a critical legal pluralist analysis of the English case $R$ (on the application of Begum) $v$ Headteacher and Governors of Denbigh High School [2007] 1 AC 100. The case concerns whether a state school's decision to exclude a pupil (Shabina Begum) for wearing an Islamic veil (a jilbab, which is a long coat-like garment which covers the whole body except the hands and face) infringed her right to manifest her religion and her right to an education protected under Articles 9 and 2 (of the First Protocol) of the European Convention of Human Rights 1950. The various court decisions of the case determine that both Articles 9 and 2 cannot be relied upon for claims related to the accommodation of religious dress in state schools. Compared with doctrinal legal scholarship and traditional legal pluralist analyses of the case, both criticised for essentialising normative orders and communities, a critical legal pluralist analysis provides the advantage of focusing on the subjective beliefs of a legal subject. Undertaking a critical legal pluralist approach as a legal methodology, rather than more traditional legal analyses, exposes and defeats various assumptions which surround the practice of veiling.
\end{abstract}

Keywords: Religion, family and personal law, the English legal system, law-making, legal pluralism

JEL Classifications: Z12, K36, K41, K 49

Amy Jackson

Ph. D. Candidate

School of Law, University of Reading, England

a.r.jackson@reading.ac.uk 


\title{
A Critical Legal Pluralist Analysis of the Begum Case
}

\author{
Amy Jackson*
}

This paper assesses the advantages for legal scholars to undertake a critical legal pluralist analysis of the English case $R$ (on the application of Begum) $v$ Headteacher and Governors of Denbigh High School (hereinafter Begum). ${ }^{1}$ A critical legal pluralist analysis highlights the significance of questioning the narrative account of legal subjects and exposes his/her view of their own individuality. The assessment is achieved by comparing a critical legal pluralist analysis of the case with both doctrinal and traditional legal pluralist analyses.

Begum asks whether the wearing of religious dress should be accommodated by a state school uniform policy. I argue that questioning what the respondent of the case (Shabina Begum) views as law has the advantage of refuting various assumptions surrounding the practice of Muslim women wearing the Islamic veil (in its many forms). ${ }^{2}$ These assumptions create an exceptional circumstance whereby the consideration of a legal subject's subjective belief is of central importance. The present paper provides an argument in favour of further empirical work to be conducted in this area.

The paper is divided into two parts. The first outlines the facts and various court decisions of Begum and considers the comments of doctrinal scholars on the case. The second part presents both legal pluralist and critical legal pluralist analyses and argues that the latter is crucial to a legal interpretation of the issues at stake.

\section{PART I: THE BEGUM CASE}

This part of the paper details the judicial history of Begum and reviews a variety of opinions of the case from doctrinal literature. It begins by, first, presenting the High Court's decision of the case; second, it outlines the decision of the Court of Appeal; and, finally, it provides an account of the House of Lords' judgment (both majority and minority opinions). The various court decisions of the case, using different reasoning and resulting in several outcomes, demonstrate that accommodation of religious dress by state school uniform policies is a contentious issue. The final section of this part of the paper describes the legacy of Begum.

\footnotetext{
${ }^{*}$ Ph. D. Candidate, School of Law, University of Reading, England. Email: a. r. jackson@reading.ac.uk

${ }^{1} R$ (on the application of Begum) v Headteacher and Governors of Denbigh High School [2007] 1 AC 100; [2006] UKHL 15; [2006] 2 WLR. 719; [2006] HRLR 21.

2 The generic term 'veil' follows Natasha Brakht, “Objection Your Honour! Accommodating Niqab-Wearing Women in the Courtrooms," in Robert Grillio, et al. (Eds), Legal Practice and Cultural Diversity (London: Ashgate, 2009$) 133$ use of the term in order to refer to the multiple ways which women cover their faces/heads/bodies and is in line with opponents who conflate these different types of covering.
} 


\section{A. FACTS OF THE CASE}

The location of Denbigh High School is within a multi-cultural and multi-faith community in Luton (a small suburban town north of London). Over the course of several years the Headteacher and Governors of the school engaged with the local community in order to establish a uniform policy which was sensitive to the cultural diversity of the area. The school's uniform policy allows girls three options of dress: wearing a skirt; trousers; or, a shalwar kameeze (the shalwar consists of trousers which are wide at the waist and narrow at the ankle and the kameeze is a long shirt or tunic). Girls may also wear a hijab (headscarf) in the colour of the school uniform (navy blue).

Begum had been a pupil at Denbigh High School since 2000 and wore a shalwar kameeze. She says that as she grew older she became more interested in her religion, which she interprets as obligating women (over the age of 13) to cover their bodies, apart from their hands and face. The school uniform policy requirements no longer conformed to Begum's religious obligations as the white shirt revealed her arms, the skirt did not cover her ankles, and both the trousers and a shalwar kameeze displayed the shape of her body. In 2002 Begum decided to wear a jilbab (a long coat-like garment which covers the whole body except the hands and face) to school. Before she could enter the school premises she was asked by a teacher to return home to change into an appropriate uniform.

\section{High COURT DeCISION}

Begum initially brought her case to the administrative division of the High Court as a claim of judicial review and sought damages for having been refused admission to school while she wore a jilbab. ${ }^{3}$ Begum relied on rights granted to her under the European Convention of Human Rights and Fundamental Freedoms (hereinafter the Convention). ${ }^{4}$ These were, to manifest her religion (Article 9) and the right to an education (Article 2 of the First Protocol). The High Court was asked to consider four general questions. These were:

- Was the refusal to admit Begum to school while wearing a jilbab unlawful exclusion?

- Had there been an infringement of Begum's right to manifest her religion under Article 9(1) of the Convention?

- Was the infringement of Begum's right to manifest her religion justified under the provisions of Article 9(2) which require that limitations be prescribed in law and are necessary

\footnotetext{
${ }^{3} R$ (on the application of Begum) $v$ Headteacher and Governors of Denbigh High School [2004] EWHC 1389 (Admin).

${ }^{4}$ European Convention of Human Rights and Fundamental Freedoms 1950 ETS No 5. The Convention is incorporated into English law by the enactment of the Human Rights Act 1998.
} 
to a democratic society, in order to uphold such interests as public safety or to protect the rights and freedoms of others?

\section{- Was Begum's right to an education under Article 2 of the First Protocol also infringed?}

Bennett J, sitting in the High Court, dismissed Begum's application for judicial review and damages. His response to the four questions put to the Court were: first, the Begum had not been unlawfully excluded from school: exclusions must be on disciplinary grounds. ${ }^{5} \mathrm{~A}$ Headteacher may exclude a pupil on disciplinary grounds for a fixed period (no longer than 45 days in one school year) or permanently. ${ }^{6}$ The Department for Education and Skills guidelines for Headteachers and Governors stipulate that exclusions should not be used for breaches of school uniform rules. ${ }^{7}$ However, Bennett J held that if Begum was excluded it was "for her refusal to abide by the school uniform policy rather than her beliefs as such" ${ }^{8}$ Begum had not been unlawfully excluded from school: she had chosen not to attend.

Second, even if Begum had been unlawfully excluded from school, her right to manifest her religion under Article 9(1) had not been infringed. Bennett J's decision about whether Article 9(1) was applicable to the case centred on the differing views held amongst Islamic scholars in relation to the appropriate level of modesty Muslim women should practice. Followers of Sunni and Shi'a Islam are the two main groups of Muslims in Britain and the practise of Islam varies in relation to multiple schools of thought. ${ }^{9}$ On the one hand, giving an opinion on behalf of the school, Anas Abushudy (Deputy Director General of the London Central Mosque Trust, and Chairman of the Religious Affairs Department) states that

looking around the Muslim world, we find an amazing variety of garments which meet [the] requirements. Also, the clothes of women differ from country to country, and in some countries differ from region to region... Here the important thing is that the Muslim women dress within Islamic guidelines. ${ }^{10}$

Abushudy outlines the diverse interpretations of dress practised by Muslim women and emphasises that they have an obligation to follow Islamic religious rules. He goes on to state that the general consensus of Muslim scholars finds a shalwar kameese acceptable dress. On

\footnotetext{
${ }^{5}$ s. 64(4) School Standards and Framework Act 1998 and s.52(10) Education Act 2002.

${ }^{6}$ Ib., s. 64(1) and (2) 1998 Act and s. 52(1) 2002 Act.

7 Point 6.4 of the Department of Education and Skills Circular 10/99, 'Social Inclusion: Pupil Support' (July 1999) and point 21(e) Department of Education and Skills Guidance 0087/2003, 'Improving Behaviour and Attendance: Guidance on Exclusion from Schools and Pupil Referral Units' (July 2003). However, point 12 of the Department for Children, Schools and Families, 'Guidelines to Headteachers and Governor's', in October 2007, stipulates that exclusions for breach of uniform policy may be an appropriate response if the pupils refusal is "persistent and defiant". Available online at: www.teachernet.gov.uk/management/atoz/u/uniform/ [accessed on 28 ${ }^{\text {th }}$ May 2010].

${ }^{8}$ High Court decision, supra note 3 , at 74.

${ }^{9}$ For a further discussion of the various Muslim communities in Britain see Samia Bano, "Muslim South Asian Women and Customary Law in Britain," Vol. 4, Journal of South Pacific Law 6 (2000) 9.

${ }^{10}$ High Court decision, supra note 3 , at 16.
} 
the other hand, giving an opinion on behalf of Begum, Ahmed Beouafi (from the Centre for Islamic Students in Birmingham) states that that the wearing of a shalwar kameeze was not a modest covering for the requirements of Islam. ${ }^{11}$ Interestingly, Masood Hasin (from the Luton Council of Mosques) advised the school that wearing a shalwar kameeze was satisfactory to "the majority of the Muslim community". ${ }^{12}$ In light of the contradictory views of Abushudy and Beouafi, Hasin provides an accurate account as he highlights that a minority of members of the Muslim community would not find the covering of a shalwar kameeze appropriate. Bennett J, however, referred to jurisprudence of the European Court of Human Rights in which the Court held that a claimant's actions must manifest his/her religion or belief, as opposed to being merely motivated by it. ${ }^{13}$ Bennett J therefore held that Article 9(1) had not been infringed as by wearing a jilbab Begum was not manifesting her religion: her refusal to abide by the uniform policy was only motivated by her beliefs.

Thirdly, even if Begum's right to manifest her religion under Article 9(1) of the Convention had been infringed, this limitation was justified under Article 9(2). The school's uniform policy fulfilled the requirement of Article 9(2) to be prescribed by law (the policy was stipulated in a document given to the families of students prior to their attendance at the school and after each summer holiday). One reason put forward by the Headteacher and teachers of the school for not allowing Begum to wear a jilbab was due to health and safety concerns. The Deputy Headteacher argued that a "flowing garment such as the one the [Begum] wishes to wear could get caught in the flame of a Bunsen burner or upset and break glass equipment leaving sharp fragments or knock equipment over causing a spillage of chemicals" ${ }^{14}$ Bennett J dismissed such a concern due to evidence from other schools (e.g. the Al-Risaala School in south London allows the wearing of the jilbab and Cheltenham Ladies' College permits long skirts to be worn). ${ }^{15}$ There have been no health and safety concerns related to the uniform policies in either of these schools. However, Bennett J found that Denbigh High School's uniform policy was "reasoned, balanced and proportionate" to the legitimate aim of social cohesion in a multi-cultural and multi-faith school. ${ }^{16}$ As the Headteacher and Governors had done everything in their power to negotiate a culturally sensitive uniform policy an infringement of Begum's right to manifest her religion was justified.

Finally, Bennett $\mathrm{J}$ held that there had been no infringement of Begum's right to an education under Article 2 of the First Protocol. This was because she could have continued to receive an

\footnotetext{
${ }^{11} \mathrm{lb}$., at 20 .

12 lb., at 40 - 48. Emphasis added.

${ }^{13}$ See Arrowsmith v United Kingdom [1978] 19 DR 5.

${ }^{14}$ High Court decision, supra note 3 , at 83.8 .

${ }^{15} \mathrm{lb}$.

${ }^{16} \mathrm{lb}$., at 91 .
} 
education, either by complying with the uniform policy, or, by attending a different school which allowed a jilbab to be worn.

In summary of the High Court's decision: Begum had not been unlawfully excluded from school; there had been no infringement of her right to manifest her religion under Article 9(1) of the Convention; even if there had been such an infringement, this was justified by the school under Article 9(2); and, there was no infringement of Article 2 of the First Protocol. The claim for judicial review was accordingly dismissed by Bennett $\mathrm{J}$.

\section{Decision of the Court of Appeal}

Begum appealed the High Court's decision to the Court of Appeal. ${ }^{17}$ By 2004 she was attending another school which permitted the wearing of a jilbab and merely sought declaratory relief, rather than damages, in relation to her alleged exclusion from Denbigh High School. Begum won her appeal. In relation to the four questions previously put to the High Court the Court of Appeal provided starkly different answers. First, it was held that the Begum had been excluded from school and this was unlawful. She had, in effect, been told not to attend school unless she complied with the uniform requirements. ${ }^{18}$

Second, Begum's right under Article 9(1) of the Convention had been infringed. Brooke LJ referred to the European Court of Human Rights case of Kokkinakis v Greece in which the Court held that

[w] hile religious freedom is primarily a matter of individual conscience, it also implies, inter alia, freedom to manifest [one's] religion. Bearing witness on the words or deeds is bound up with the existence of religious convictions. ${ }^{19}$

Mutual religious convictions are necessary as they determine that an individual's beliefs are legitimate by the acceptance of others. Brooke $U$ referred to the dispute between Islamic scholars, previously considered by the High Court, on the level of modesty appropriate for Muslim women in order to fulfil the objective requirements of Begum's subjective belief. Brooke LJ held that there were two schools of thought: mainstream opinion and a minority view. The mainstream opinion is a liberal view, generally held by South Asian Muslims that a shalwar kameeze complies with Islamic requirements. The minority opinion, held by Begum and others, also receives respectable support in holding that a jilbab must be worn. In the case of Hasan and Chaush v Bulgaria the European Court of Human Rights decided that states are excluded from determining the legitimacy of an individual's beliefs and his/her expression of them, except in exceptional cases. ${ }^{20}$ Brooke $L$ stated that there were no exceptional

${ }^{17} R$ (on the application of Begum) $v$ Headteacher and Governors of Denbigh High School [2005] EWCA CIV 199; [2005] 1 WLR CA.

${ }^{18} \mathrm{Ib}$., per Brooke J, at 24.

${ }^{19}$ Kokkinakis v Greece [1993] 17 EHRR 397 at 31.

${ }^{20}$ Hasan and Chaush v Bulgaria [2002] 34 EHRR 1339 at 78. 
circumstances in this case; therefore, the sincerity of the Begum's religious belief was not a central issue. Article 9(1) of the Convention had been infringed by the school's decision not to admit Begum whilst she wore a jilbab and it was not for the court to consider the validity of her subjective beliefs.

Third, the Court could not hold that the infringement of Begum's right under Article 9(1) of the Convention were justified under Article 9(2). Brooke $L$ made a procedural point in relation to the school's decision to exclude Begum. He held that the school as an emanation of the state had not followed the proper decision-making structure provided under the Human Rights Act. ${ }^{21}$ The Headteacher and Governors had started from the position that the uniform policy was there to be observed, and that if Begum did not agree with the policy she was free to attend another school. Brooke LJ stated that the school had not recognised that Begum had a right under Article 9(1) of the Convention and that the onus lay on the Headteacher and Governors to justify their interference in that right under Article $9(2) .{ }^{22}$ In his judgment, Mummery $L$ emphasised the importance of the statutory obligation for children to be educated. He stated that this obligation distinguished the relationship between Headteachers and pupils from a contractual one (such as that between employers and employees). ${ }^{23}$ It could not be held whether an infringement of Begum's right under Article 9(1) was justified as the school had not followed the correct decision-making procedure under the Human Rights Act.

Finally, the Court agreed with Bennett $L J$ that there had been no infringement of Begum's right to an education under Article 2 of the First Protocol.

On the basis that Begum had been excluded from school and her exclusion was unlawful; her right to manifest her religion had been infringed; and, that it was not clear if the infringement was justified as the Headteacher and Governors had not followed the correct decision-making procedure, the judgments of Mummery $L$ and Scott Baker $L$ agreed with the decision of Brooke $\mathrm{LJ}$ and the Court allowed her appeal.

\section{HOUSE OF LORDS' JUDGMENT}

The Court of Appeal's overtly procedural approach to the case has received criticism from legal scholars. ${ }^{24}$ The school consequently appealed the decision to the House of Lords. ${ }^{25}$ By a 3:2

\footnotetext{
${ }^{21}$ Decision of the Court of Appeal, supra note 17, at 49. Brooke $\amalg$ stated the decision-making structure which the school should have followed at 75.

22 lb., at 76.

${ }^{23}$ lb., at 84 .

${ }^{24}$ For example, Thomas Poole, "Of Headscarves and Heresies: The Denbigh High School Case and Public Authority Decision-Making under the Human Rights Act," Public Law 685 (Win. 2006) argues that the Court of Appeal was incorrect as it introduced a new formalistic approach in relation to decisions made by public authorities.
} 
majority the House of Lords overturned the Court of Appeal's decision, holding that the school's uniform policy did not infringe Begum's right under Article 9 of the Convention. The House of Lords reconsidered the four questions originally put to the High Court, first, whether the refusal to admit Begum to school wearing a jilbab amounted to unlawful exclusion; second, if this were found to be the case, whether the exclusion amounted to an infringement of her right to manifest her religion under Article 9(1) of the Convention; third, if Begum's right under Article 9(1) were infringed, whether such a limitation was justified by the school under Article 9(2) of the Convention; and finally, whether there was a breach of Article 2 of the First Protocol.

In relation to the first question the majority of the House of Lords, Lords Bingham, Hoffmann and Scott, found that Begum had not been unlawfully excluded; she could always have attended if properly dressed. ${ }^{26}$ In criticising the school's decision, Booth (Begum's counsel) argued that the uniform policy was undermined by Muslim girls being allowed to wear hijabs (in the colour of the school uniform) as this identified the wearers as Muslim and so it would have made little difference to allow the wearing of jilbabs in the same way . Lord Scott held, however, that "[t]here is not much point in having a school uniform policy if individual pupils can decide for themselves what to wear". ${ }^{27}$ As Begum could have attended school by wearing the appropriate uniform she had not been unlawfully excluded from school.

Second, even if Begum had been unlawfully excluded by the school, there was no breach of Article 9(1) of the Convention. Lord Bingham found that Article 9(1) was "engaged and applicable" as Begum sincerely held the religious belief she professed. He stated, however, that the European Court of Human Rights' decision of Kalaç $v$ Turkey affirmed that

Article 9 [does] not protect every act motivated or inspired by a religion or belief...in exercising his freedom to manifest his religion, an individual may need to take his specific situation into account. ${ }^{28}$

The above test is called "the specific situation rule". Lord Bingham summarised the European Court of Human Rights' interpretation of this rule to be that there is no interference with the right to manifest one's religious belief where an individual has voluntarily accepted employment (or a similar role) which does not accommodate that practice or observance and there are other means open to practise or observe the religion without undue hardship or inconvenience.

In his judgment Lord Hoffmann referred to the reasoning of the European Court of Human Rights in Jewish Liturgical Association Cha'are Shalom Ve Tsedek v France. ${ }^{29}$ In this case the

${ }^{25} R$ (on the application of Begum) $v$ Headteacher and Governors of Denbigh High School [2006] HRLR 21; [2006] 2 WLR 719; [2007] 1 AC 100.

${ }^{26}$ Ib., at 38 .

${ }^{27} \mathrm{lb}$., at 84 .

${ }^{28}$ Kalaç v Turkey [1997] 27 EHRR 552 at 27.

${ }^{29}$ Jewish Liturgical Association Cha'are Shalom Ve Tsedek v France [2000] 9 BHRC 27; [2006] HRLR 21. 
Court considered whether French law, which prohibited the slaughter of meat as required by the Jewish faith, was an infringement of Article 9. The European Court of Human Rights held that

there would be interference with the freedom to manifest one's religion [in this case] only if the illegality of performing ritual slaughter made it impossible for ultraorthodox Jews to eat meat from animals slaughtered in accordance with the religious prescriptions they considered applicable. ${ }^{30}$

The decision of the Jewish Liturgical Association case created an "impossibility test" in relation to the specific situation rule of the infringements under Article 9. Begum's ability to attend another school was therefore an important factor in the House of Lords' judgment. There was no evidence that attending another school would cause Begum any difficulty; indeed, by attending Denbigh High School she had already chosen to attend a school outside her catchment area. Thus, there was no infringement to her right under Article 9(1).

Third, even if there had been an infringement of Begum's right under Article 9(1), the House of Lords found that this limitation was justified under Article 9(2). The uniform policy was prescribed by law and legitimate and proportionate to the desire for social cohesion in a culturally diverse school. Following the reasoning of the European Court of Human Rights in the case of Sahin $v$ Turkey ${ }^{31}$ which applied the doctrine of the "margin of appreciation" in relation to the accommodation of religious dress by state parties, it was held that the school was given power by Parliament to decide on the appropriateness of its own school uniform policy. ${ }^{32}$ The school was therefore justified in creating a uniform policy which protected the rights and freedoms of others by standardising the dress required. As the school had acted responsibly in its decision the limitation of Begum's rights was justified.

Finally, the House of Lords held that there was no infringement of Begum's right to an education under Article 2 of the First Protocol. The interruption to her education was a result of Begum's own unwillingness to comply with the rules of uniform policy.

Therefore, the majority of the House of Lords held that: Begum had not been unlawfully excluded from school; even if she had been, her right to manifest her religion under Article 9(1) had not been infringed; in any event, the school was justified in infringing the right under Article 9(2) in order to protect the rights and freedoms of others; and, finally, there was also no infringement of the right to an education under Article 2 of the First protocol.

\footnotetext{
${ }^{30} \mathrm{lb}$., at 80. Emphasis added.

${ }^{31}$ Sahin v Turkey [2007] 44 ECHR 5.

32 House of Lords' judgment, supra note 25, at 33.
} 
Doctrinal scholars have offered various comments on the House of Lords' judgment of Begum. Mohammad Mazher Idriss supports the House of Lords' judgment as it

effectively maintains the current right of each school to decide its policy on school uniforms...Denbigh High School did not reject [Begum's] request to wear the jilbab out of hand: rather, it took advice, and was told that its existing policy conformed to the requirements of mainstream Muslim opinion. ${ }^{33}$

Idriss argues that the majority opinion of the House of Lords was the correct approach to the practice of veiling as it upholds the autonomy of state schools to decide their uniform policies.

Idriss' argument supports the dialogue between state schools and mainstream religious opinions when formulating uniform policies, which highlights the importance of an objective element in relation to an individual's subjective religious belief. The Headteacher and Governors of Denbigh High school were, therefore, correct in engaging with parents and mosques in the wider religious and cultural community in order to understand the beliefs of others in the community.

On the other hand, Mark Hill and Russell Sandberg critique the House of Lords' judgment for the universal effect it gives to the specific situation rule because this rule was taken out of its particular contractual context. In referring to the Kalaç and Jewish Liturgical Association cases, Hill and Sandberg contend that the House of Lords "correctly elucidated the "'specific situation"' rule but applied it to the case without explanation". ${ }^{34}$ Mummery LJ made the same point in his Court of Appeal judgment. He stated that Begum could not be compared to employee cases. Being free to attend another school in order to receive an education is not a contractual choice as there is a statutory duty to provide education to children. ${ }^{35}$ The universal application of the specific situation rule does not match Lord Bingham's statement that "this case concerns a particular pupil and a particular school in a particular place at a particular time" ${ }^{36}$ If this situation is so particular, how can it be analogous employment decisions?

In their critique of the majority in the House of Lords decision Hill and Sandberg also refer to Scarman LJ'S statement (made prior to the enactment of the Human Rights Act) in Ahmad v Inner London Education Authority that the English legal "system must be made sufficiently flexible to accommodate....beliefs and their observances". ${ }^{37}$ Scarman LJ's statement encourages

\footnotetext{
${ }^{33}$ Mohammad Mazher Idriss, "Dress Codes, the Right to Manifest Religion and the Human Rights Act 1998: The Defeat of Shabina Begum in the House of Lords," Vol. 11, Issue No. 1, Coventry Law Journal 58 (2006) at 75. See also supra note 7 to, point 4 of the Department for Children Schools and Families guidelines which states that schools should consult the opinions wider community and ethnic minorities in relation to their policies.

${ }^{34}$ Mark Hill and Russell Sandberg, "Is Nothing Sacred? Clashing Symbols in a Secular World," Public Law 488 (Aut. 2007) at 497.

${ }^{35}$ Decision of the Court of Appeal, supra note 17, per Mummery $\sqcup$ at 84 .

${ }^{36}$ House of Lords' judgment, supra note 25 , at 2.

${ }^{37}$ Ahmad v Inner London Education Authority [1978] QB 36 at 48.
} 
judges to uphold the protections of international human rights mechanisms in relation to religious liberty.

Hill and Sandberg also refer to Lord Nicholls' statement in $R$ (on the application of Williamson) $v$ Secretary of State for Education and Employment (made after the enactment of the Human Rights Act) that

it is not for the court to embark on an inquiry into the asserted belief and judge its "validity" by some objective standard such as the source material upon which the claimant founds his belief or the orthodox teaching of the religion in question or the extent to which the claimant's belief conforms to or differs from the views of others professing the same religion. Freedom of religion protects the subjective belief of an individual. ${ }^{38}$

Both Scarman L (implicitly) and Lord Nicholls' (explicitly) call for the subjective belief of religion to be upheld. The media has reported that Begum felt that it was "an obligation upon Muslim women to wear [a jilbab], although there are many other opinions". ${ }^{39}$ If this is an accurate account, Begum believes that her religion obligates her to wear a jilbab. Hill and Sandberg argue that it is wrong that the House of Lords in Begum did not follow this reasoning. Instead, the reasoning of Lords Bingham, Hoffmann and Scott which gives universal effect to the specific situation rule brings "English law in line with the discredited "impossibility" test". ${ }^{40}$ This means that "[p]rovided that the right to manifest can be exercised elsewhere, it seems that the court will be entitled, or even obliged, to find that there had been no interference". ${ }^{41}$ The case resulted in Begum simply attending a school which allowed her to wear a jilbab.

Hill and Sandberg argue that the reasoning of Lord Nicholls and Baroness Hale, writing in the minority, is correct in law. ${ }^{42}$ This legal approach was taken by the European Court of Human Rights in the more recent Sahin case.

${ }^{38} R$ (on the application of Williamson) $v$ Secretary of State for Education and Employment [2005] UKHL 15; [2005] 2 A.C. 246 at 22.

39 BBC News. 'School Wins Muslim Dress Appeal.' 22 ${ }^{\text {nd }}$ March 2006. Available online at: http://news.bbc.co.uk/1/hi/education/4832072.stm [accessed on 17th May 2010]. Emphasis added.

${ }^{40}$ Hill and Sandberg, supra note 34 , at 448.

${ }^{41} \mathrm{lb}$., at 499.

${ }^{42} / b$. , at 498. 


\section{MINORITY OPINION OF THE HOUSE OF LORDS}

The minority opinions of Lord Nicholls and Baroness Hale agreed with the majority decision of the House of Lords in the result of the case, however, they provided different answers to the questions put to the High Court. Lord Nicholls and Baroness Hale held that Begum's right to manifest her religion under Article 9(1) of the Convention was infringed, but that the school was justified in infringing her right under Article 9(2). Lord Nicholls commented this approach required the Headteacher and Governors to "explain and justify [their] decision[s]". ${ }^{43}$

Baroness Hale is particularly noteworthy as she considered Begum's subjective religious belief in detail. Baroness Hale held that British Muslim women were exercising their individual autonomy by choosing whether or not to veil and that this decision must be respected. There are many reasons why some Muslim women choose to cover their bodies, heads and faces. For example, some Muslim women view it as an obligation arising out of Islamic texts such as this verse of the Qur'an

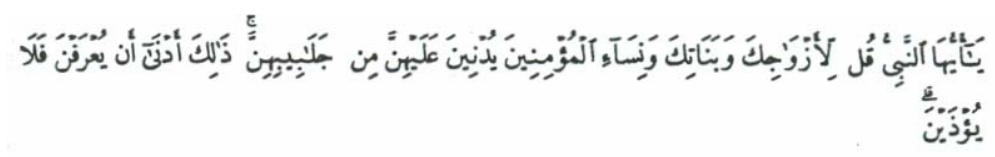

[O Prophet, tell your wives and daughters, and believers' wives as well, to draw their cloaks close around themselves. That is more appropriate so that they may be recognized and not molested]. ${ }^{44}$

The verse encourages women to cover themselves. Two reasons given for this practice are: first, it benefits the recognition of Muslim women as a group within society; and second, it protects women from molestation. ${ }^{45}$ Lila Abu-Lughod recently drew an analogy between the burqa and a "mobile home" as the burqa enables "women to move out of segregated living spaces while still observing the basic moral requirements of separating and protecting women from unrelated men". ${ }^{46}$ Yasmin Alibhai-Brown also suggests that a young woman "may have chosen the $[$ hijab] as a mark of her defiant political identity and also as a way of control over her body" ${ }^{47}$ The wearing of the veil has multiple meanings and takes many forms. Baroness

\footnotetext{
${ }^{43}$ House of Lords' judgment, supra note 25, at 41.

${ }^{44}$ Qur'an: The Confederates verse 33.59 translation from T. B. Irving, Kurshid Ahmad and Manazir Ahsan (trans.), The Qur'an: Basic Teachings, (Wiltshire: Cromwell Press Ltd, 1992) 211.

${ }^{45}$ For a further discussion on the multiple interpretations of the veil by Muslim women see Manisuli Ssenyonjo, "Moslem Women, Religion and the Hijab: A Human Rights Perspective,"' Vol. 14, Issue No. 1, South East African Journal of Peace and Human Rights 148 (2008) for a further discussion on the multiple interpretations of the veil by Muslim women.

${ }^{46}$ Lila Abu-Lughod, "Do Muslim Women Really Need Saving? Anthropological Reflections on Cultural Relativism and Its Others," Vol. 104, Issue No. 3, Anthropology 783 (2002) 785.

${ }^{47}$ Yasmin Alibhai-Brown, Who Do We Think We Are? Imagining the New Britain, (London: Penguin Books, 2000) 246.
} 
Hale held that if a woman freely chooses to adopt this way of life, it is not for others, including other women (such as liberal feminists), to criticise or prevent her.

One concern of liberal feminists is that Muslim women, like Begum, do not have an adequate choice in whether they wear the Islamic veil. ${ }^{48}$ Indeed, the issue of choice was raised by the Lords: whether Begum personally chose to veil or was following the direction of her brothers was expressly queried. ${ }^{49}$ Begum's parents originated from Bangladesh. Her father died in 1992 and her mother, who did not speak English, died in 2002. Begum had two older sisters and two elder brothers who looked after her. One of Begum's brothers confronted the teacher who turned her away from Denbigh High School and her other brother was her litigant friend in the House of Lords case.

Baroness Hale referred to the Parekh Report on the Future of Multi-Ethnic Britain (Runnymede Trust), made in 2000, which states that "[i]n all traditions, religious claims and rituals may be used to legitimise power structures rather than to promote ethical principles, and may foster bigotry, sectarianism and fundamentalism" ${ }^{50}$ Following this view Baroness Hale stated that a strict Islamic dress code is imposed upon women, not for their own sake but to serve the ends of others. This denies women freedom of choice and equal treatment. She went on to state the importance of the age of Begum's age, highlighting her adolescence. Adulthood was held to be when an individual has the capacity to make autonomous moral judgements against the dominance of cultural patriarchy. The fact that Begum was not yet a fully formed adult justified interference in her choices as "[i]t cannot be assumed, as it can with adults, that [her] choices are the product of fully developed individual autonomy". ${ }^{51}$ Baroness Hale, therefore, agreed with Lord Nicholls that the school had been correct in devising a school uniform policy to suit the social conditions of the school; cultural and religious diversity was provided for and this was a thoughtful and proportionate response. ${ }^{52}$ For these reasons Baroness Hale agreed with the majority result allowed the appeal.

Gareth Davis asserts that the problem with the various court judgments and opinions of the Begum case is that

\footnotetext{
${ }^{48}$ See the arguments supported by liberal feminists in Susan Moller Okin, "Is Multiculturalism Bad for Women?" in Sussn Moller Okin et al. (Eds), Is Multiculturalism Bad for Women? Susan Okin Miller With Respondents, (Princeton: Princeton University Press, 1999) 7.

${ }^{49}$ See the House of Lords' judgment, supra note 25, per Lord Scott at 79-80.

${ }^{50}$ Para. 17.3 Parekh Report (2000). 'The Future of Multi-Ethnic Britain' (Runnymede Trust) 236-237.

${ }^{51}$ House of Lords' judgment, supra note 25, at 93.

52 lb., at 98 .
} 
they seem to judge the wearer of religious clothing not according to the meaning or importance that they attribute to it but according to that attributed by others. Whose belief is under discussion here ${ }^{53}$

Davis' question is important as, for example, the majority judgment of the House of Lords found in favour of the protection of the rights and freedoms of others; in other words, what others read into the significance of the religious dress was deemed to be more important than the subjective belief of the individual. The school had gone to great lengths to devise a policy which respected and included Muslim beliefs but it was feared that acceding to Begum's request would have adverse repercussions on other female pupils. Davis highlights that Begum "was not accused of individual behaviour that might threaten or intimidate others nor was it claimed that jilbab wearing girls would generally actively behave in such a way" ${ }^{54}$ However, the view that others feel threatened or intimidated by religious dress was seen as significant. The minority opinion of Baroness Hale which considered Begum's subjective belief in some detail and also stated the significance of the dress attributed by others in holding that, because of her young age, Begum was likely to be influenced by her family (notably her brothers) in relation to the garments she wore. Davis makes two important observations: first, disagreement with others is no reason to prohibit them from living according to their religious beliefs; and, second, veils are only garments or clothes. He would agree with Lord Nicholls' reasoning in the Williamson case that subjective belief must be protected by the right to freedom of religion.

\section{B. LEGACY OF THE CASE}

Sandberg argues that the legacy of the Begum case is a "flawed precedent that has constrained religious liberty in England and Wales" ${ }^{55}$ This is because Begum provides that if the right to manifest religion can be exercised elsewhere (e.g. in another school) courts are obliged to find that there has been no interference with the right, even though such reasoning was distinguished by the European Court of Human Rights in the Sahin case. Therefore, the Begum decision has meant that in subsequent claims related to the manifestation of one's religious belief through the wearing of garments or symbols will not be successful. For example, $R$ (on the application of $X) \vee$ Headteachers and Governors of $Y$ School also concerned a school's refusal to allow a Muslim girl to wear a veil (a niqab or the face veil). Silber J stated that the Begum case was "an insuperable barrier" to the success of the claim. Following the Begum precedent, he held that there was no interference with the claimant's right under Article 9(1) of the Convention, and even if there had been such interference that it was justified under Article $9(2) .^{56}$

\footnotetext{
${ }^{53}$ Gareth Davis."'Banning the Jilbab: Reflections on Restricting Religious Clothing in Light of the Court of Appeal in SB v Denbigh High School," Vo. 1 European Constitutional Law Review 511 (2005) 519. Emphasis added.

${ }^{54} \mathrm{lb}$., at 520 .

${ }^{55}$ Russell Sandberg, "The Changing Position of Religious Minorities in English Law: The Legacy of Begum," in Robert Grillo, et al. (Eds), Legal Practice and Cultural Diversity, (London: Ashgate, 2009) 267.

${ }^{56} R$ (on the application of X) $v$ Headteachers and Governors of $Y$ School [2007] EWHC 298; [2007] All ER (D) 267, at 100.
} 
Begum has created a barrier to the success of new claims on the accommodation of religious dress under Article 9 of the Convention. Claims now have to be made in relation to other human rights provisions. For example, the case of $R$ (on the application of Watkins-Singh) $v$ Aberdare Girls' High School Governors, was concerned with whether a school was entitled to prevent a Sikh girl from wearing a kara (a plain steel bangle, 50 millimetres wide, and of great significance to Sikh ethnic identity and religious observance). ${ }^{57}$ The claim was successful, but it was based on racial grounds under the provisions of Race Relations Act 1976, rather than the right enshrined in Article 9. Currently, however, no similar legislative protection is available to Muslim women on racial grounds.

Alternatively, as Begum also relied on Article 2 of the First Protocol of the Convention which provides for the right to an education this approach may be a more successful ground for new claims. Manisuli Ssenyonjo argues that Muslim women have less access to education in their culture than men and therefore "general bans on the Islamic dress in schools might lead to further discrimination against girls and women in education".$^{58}$ Potential infringements to a Muslim woman's right to an education is an important consideration. However, rather disappointingly, not one of the Begum decisions held that there was a breach of the right to an education. But the issue of such a breach may not have been explored in depth in Begum because of the statutory requirement that children receive an education.

Furthermore, Jill Marshall argues that rather than the wearing of the Islamic veil being supported by the right to manifest one's religion provided under Article 9 of the Convention, it could be protected under the right to private and family life provided under Article $8 .^{59}$ She maintains that the latter right is embedded in liberal notions of the autonomous self and points to jurisprudence of the European Court of Human Rights which establishes that the autonomous individual forms part of a larger social network. In other words, individuals have the autonomy to choose the aspects of their larger social network they wish to pursue, or not, as the case may be. ${ }^{60}$ Responding to Marshall, Cowan argues that the right enshrined in Article 8 is also a qualified right, therefore, also justifiably infringed by limitations necessary to a democratic society. She insists that

[r]educing the decision to wear a headscarf to an autonomous, free, individualistic preference confines a complicated and multilayered combination of symbolic and

\footnotetext{
${ }^{57} R$ (on the application of Watkins-Singh) v Aberdare Girls' High School Governors [2008] EWHC 1865 (Admin).

${ }^{58}$ Ssenyonjo, supra note 45, at 197.

${ }^{59}$ See Jill Marshall, “Women's Right to Autonomy and Identity in European Human Rights Law: Manifesting One's Religion," Vo. 14, Issue No. 3, Res Publica 177 (2008).

${ }^{60}$ This argument follows the approach of liberal multiculturalists, such as Will Kymlicka, Multicultural Citizenship: A Liberal Theory of Minority Rights, (Oxford: Claredon Press, 1995).
} 
practical meanings within the narrow and impoverished framework of the liberal choosing self. ${ }^{61}$

Cowan contends, instead, that "[l]ike culture, religion is not (per)formed and developed by one individual in isolation from each other, but by the interactions and lived interwoven experiences of individuals and groups". ${ }^{62}$ Both culture and religion are interwoven experiences of groups and their members. This argument brings forth the very question of how these interwoven experiences of groups and individuals can be captured in law.

\section{PARt II. Legal PluRalist AnalyseS}

This part of the paper puts forward a different approach to the questions raised in Begum: an approach that starts from the assumption of the multi-faceted nature of human experience legal pluralism. The first section outlines the basic tenets of legal pluralism and illustrates what a traditional legal pluralist analysis of the case might look like. Whilst such an analysis provides account of various laws which operate, interact and conflict with one another, it lacks a grasp of the multi-faceted nature of individual experiences. The second section summarises what a critical legal pluralist perspective might offer and suggests that this latter analysis provides overwhelming advantages to a legal interpretation of the Begum case.

\section{A. Traditional legal Pluralism}

A legal pluralist image of law is a multi-sited phenomenon with a variety of laws existing and interacting within a particular social situation. John Griffiths develops a definition of legal pluralism based upon the meaning of 'pluralism' as the presence of more than one of a particular thing in a specified place. ${ }^{63}$ In the case of legal pluralism law is the particular thing of which more than one is present. For Griffiths, legal pluralism is "that state of affairs for any social field, in which behaviour pursuant to more than one legal order occurs" ${ }^{64}$ The social field is important as Griffiths argues that "[l]egal pluralism is an attribute of the social field and not of "law" or the "legal system". ${ }^{65}$ Griffiths' critiques doctrinal scholars for their lack of attention to social spaces "[t]he social space between legislator and subject is implicitly conceived [by docterinal scholars] as a normative vacuum" ${ }^{66}$ One example of a social space is the territory of a nation state (or state-law). Griffiths fills the normative vacuum between legislator and subject inside the nation state by theorising the existence of a plurality of normative orders (or semi-

\footnotetext{
${ }^{61}$ Sharon Cowan, "The Headscarf Controversy: A Response to Jill Marshall," Vol. 14, Issue No. 3, Res Publica 193 (2008) $196-197$.

${ }^{62} \mathrm{Ib}$., at 196.

${ }^{63}$ John Griffiths, “What is Legal Pluralism?" Vo. 24, Journal of Legal Pluralism 55 (1986).

${ }^{64} \mathrm{Ib}$., at 2.

${ }^{65} \mathrm{lb}$., at 38 .

${ }^{66} \mathrm{Ib}$., at 34 .
} 
autonomous social fields). ${ }^{67}$ The different branches of Islam or the many state schools are some examples of normative orders. Likewise, state-law is a normative order which operates, interacts, and conflicts with these surrounding normative orders. For Griffiths, law is the "selfregulation of a semi-autonomous social field". ${ }^{68}$ The various religious rules of Islam are examples of the self-regulation of a normative order and law under Griffiths' definition. The definition of law which Griffiths provides opposes the presumption by doctrinal scholars of a neatly structured legal system solely created by the modern political state (an approach he refers to as 'legal centralism'). He argues that the legal reality is "an unsystematic collage of inconsistent and overlapping parts" ${ }^{69}$ As Griffiths acknowledges the operation, interaction and conflicts between multiple normative orders, he views legal centralism to be an unrealistic myth.

Griffiths distinguishes between weak and strong legal pluralism. Legal pluralism in the 'weak' sense refers to situations in which other normative orders are incorporated within state-law. In the present case, an example of weak legal pluralism is Parliament delegating the decisionmaking power of uniform policies to state schools, such as Denbigh High School. Legal pluralism in the 'strong' sense refers to situations in which normative orders can be seen to persist outside the scope of state-law. An example of strong legal pluralism in English state-law is the practice of cultural or religious traditions within the private sphere. However, the distinction between weak and strong legal pluralism is arbitrary. Melissaris argues that strong legal pluralism can also be shown to be weak. ${ }^{70}$ The example of strong legal pluralism related to the practice of cultural diversity in the private sphere becomes weak when judges incorporate decisions on this issue into the common law system and, thus, state-law. ${ }^{71}$

As legal pluralists question which normative orders exist in a particular situation, such an analysis of Begum draws attention to the multiplicity of normative orders which operate, interact and conflict with one another. ${ }^{72}$ Several laws operate in the present case. For example: state-law is apparent in the various court judgments; human rights law on which Begum's case

${ }^{67}$ Sally Falk Moore, "Law and Social Change: The Semi-autonomous Field as the Appropriate Subject of Study," Vo. 7, Issue No. 4, Law and Society Review 719 (1973).

${ }^{68}$ Griffiths, supra note 63 , at 38.

${ }^{69}$ Ib., at 2.

${ }^{70}$ Emmanuel Melissaris, "The More the Merrier? A New Take on Legal Pluralism," Vol. 13, Issue No. 1, Social and Legal Studies 57 (2004) 60.

${ }^{71}$ See Bano, supra note 9.

${ }^{72}$ Prakash Shah also analyses the High Courts' decision of the Begum case, but he follows Masaji Chiba pluralistic approach of the three level system of law (e.g. official law, unofficial law, and legal postulates) which differs from the one presented in this paper (based on Griffiths" definition of legal pluralism). See Prakash Shah, Legal Pluralism in Conflict: Coping with Cultural Diversity in Law, (London: Glasshouse Press, 2005) 177 - 179; and Masaji Chiba, Asian Indigenous Law in Interaction with Received Law, (London: KPI. Ltd, 1986). 
was made; institutional policies (notably the uniform policy) of Denbigh High School; and the religious laws Begum viewed as obligating Muslim women to wear a jilbab.

A legal pluralist analysis of Begum would also focus on the particular interactions between the various normative orders in this situation, including, considering whether, and how, other normative orders are incorporated into state-law. Examples of such weak legal pluralism are: state school uniform policies incorporated into state-law by Parliament delegating the decisionmaking power of these rules to Headteachers and Governors; Denbigh High School adopting what is considered appropriate dress by the wider Muslim community of Luton (as per their engagement with parents and local mosques); and, the incorporation of the rights under the Convention into English state-law. ${ }^{73}$ These overlapping relationships between different normative orders are illuminated by the legal pluralist approach.

A legal pluralist analysis of Begum would also discuss the conflicts between normative orders. For example, attention would be given to the majority and minority interpretations related to the appropriate dress of Muslim women illustrated by the debate between Islamic scholars in the case. Another example is the majority of the House of Lords' interpretation of the jurisprudence of the European Court of Human Rights of Article 9. ${ }^{74}$ The result of the House of Lords' reasoning (of Lords Bingham, Hoffmann and Scott) in relation to the specific situation rule conflicts with the approach taken by the European Court of Human Rights in the Sahin case. The advantage of a legal pluralist analysis of the Begum case over the doctrinal approach is that the operation, interaction and conflicts of an array of normative orders is illuminated.

\section{B. Critical Legal Pluralism}

In their critique of Griffiths' definition of legal pluralism, Martha-Maire Kleinhans and Roderick Macdonald posit an alternative image of law, which they call 'critical legal pluralism' ${ }^{75}$ Their criticisms of legal pluralism and how they establish an alternative image of law are presented in this section of the paper.

Kleinhans and Macdonald present three criticisms of legal pluralism. First, that Griffiths' definition undermines the rule of law; second, that it is limited by an institutional perspective of law; and finally, that he presents an essentialist image of normative orders and communities. First, Griffiths' notion of legal pluralism is criticised for undermining the rule of law. ${ }^{76}$ This

\footnotetext{
${ }^{73}$ For example, Article 13(2) of the Human Rights Act directly incorporates Article 9 of the European Convention into English law.

${ }^{74}$ See the discussion on whether there is a parallel or unified system between Convention law and English administrative law in Christopher Hilson, "The Europeanization of English Administrative Law: Judicial Review and Convergence," Vol. 9, Issue No. 1, European Public Law 125 (2003).

${ }^{75}$ Martha-Marie Kleinhans and Roderick. A. Macdonald, “What is a Critical Legal Pluralism?” 12(2) Candian Journal of Law and Society 25 (1997).

${ }^{76} \mathrm{Ib}$., at 32 .
} 
criticism is given as Griffiths offers no criteria to distinguish normative orders from other forms of social ordering (such as morals, etiquette, fashion etc.). Sally Engle Merry argues that the lack of such criteria creates the dilemma: "where do we stop speaking of law and find ourselves simply describing social life?"77 She suggests that it may be "essential to see state law as fundamentally different [from other normative orders]". ${ }^{78}$ Therefore, the criticism that Griffiths' definition of legal pluralism undermines the rule of law could be overcome by acknowledging the differences between the law-like qualities of other normative orders.

The second criticism of Griffiths' definition is that he perpetuates the image of law which he opposes. Griffiths opposes the legal centralist image of law (the notion that law is only created by the modern political state). Kleinhans and Macdonald argue that under Griffiths' definition the "primacy of the institutionalised state legal order remains", which means that legal pluralists "either accept one essentialist/positivistic image of law, or several such images". ${ }^{79}$ Griffiths' definition accedes to an institutional notion of law as, for example, a state school can be viewed as a normative order because it holds the capacity to generate its own norms (such as a uniform policy) which it can enforce (by discipline pupils if they fail to comply with these norms). ${ }^{80}$ In other words, a state school is a normative order because it consists of the decisionmaking and law-enforcing processes comparable to those of the modern political state. This reasoning simply results an approach which describes multiple positivistic images of law, rather than articulating a multi-sited social phenomenon. Therefore, Griffiths' definition of legal pluralism perpetuates the legal centralist notion that law.

The final critique of Griffiths' definition of legal pluralism offered by critical legal pluralists is that his description fails to consider what legal subjects' view to be law. Kleinhans and Macdonald argue that Griffiths fails "to discuss fundamental questions about how legal subjects understand themselves and the law [simultaneously]" ${ }^{81}$ Griffiths fills the normative vacuum between legislator and legal subject by an interplay of normative orders (or semi-autonomous social fields), but does not capture the view of legal subjects caught in these situations. Instead legal subjects are viewed as abstract individuals. This view creates an essentialised notion of normative orders as homogenous entities.

Kleinhans and Macdonald overcome the view of legal subjects as abstract individuals by positing an alternative image of law. They argue that "law is essentially an explicit creation of

\footnotetext{
${ }^{77}$ Sally Engel Merry, “Legal Pluralism," Vol. 22 Issue No. 5, Law and Society Review 869 (1988) at 869- 870.

${ }^{78} \mathrm{Ib}$., at 879.

${ }^{79}$ Kleinhans and Macdonald, supra note 75, at 35.

${ }^{80}$ See Neil MacCormick, Institutions of Law: An Essay in Legal Theory, (Oxford: Oxford University Press, 2007).

${ }^{81}$ Kleinhans and Macdonald, supra note 75, at 36.
} 
human agency". ${ }^{82}$ Law is the creative capacity of legal subjects. Their argument is achieved by supplementing the legal pluralist question (in which normative orders exist) with questions about what legal subjects view as law in a particular situation. Posing both the former and the latter questions overcomes the three criticisms of Griffiths' definition of legal pluralism. First, it overcomes the need for criteria which distinguishes state-law as apart from other forms of social ordering. This is because law is viewed as only existing in the human imagination, generated within the minds of legal subjects from whatever belief they have of the law-like qualities of different normative orders.

Second, Kleinhans and Macdonald's image of law opposes an institutional notion of law as the critical legal pluralist image shifts the attention of legal scholars from the acknowledgment of the operation, interaction and conflicts between multiple normative orders which fill the normative vacuum between the legislator and the legal subject to the creative capacity of legal subjects. The critical legal pluralist approach turns the traditional agency pattern inside out. Legal subjects are viewed as 'law-inventing' not simply 'law-abiding'. ${ }^{83}$ Instead of a linear pattern of law imposed on legal subjects from above, the pattern generated by critical legal pluralists is circular. Viewing legal subjects as both law-creating and law-enforcing means that "law is the belief of those whose narrative of its prospects succeeds for the narrator". ${ }^{84}$ Law is autobiographical and is captured in the narratives of legal subjects. Following a critical legal pluralist approach, the relationship between law and legal subjects reveals its complexity.

Finally, a non-essentialist image of normative orders and communities is achieved as critical legal pluralists point towards normative orders being internally complex due to legal subjects' understanding of their own individuality. Following this purely subjective approach, legal subjects are viewed as the multiplicity of selves perceived by the modern self. The modern self is a construct and this construct has itself a constructive capacity.

Kleinhans and Macdonald point to dialogic approaches in relation to the formation of the identity of the modern self, first articulated by Charles Taylor, as best at representing how critical legal pluralism accounts for both the law-creating and law-enforcing subjects. ${ }^{85}$ Discovering one's identity is not achieved in isolation, but negotiated through dialogue, partly overt, partly internal, with others. ${ }^{86}$ This approach resonates with the complexity of the issues

82 Ib., at 27. For example see Lon. L. Fuller, "Human Interaction and the Law," Vol. 14, American Journal of Jurisprudence 1 (1969).

${ }^{83} \mathrm{lb}$., at 39.

${ }^{84} \mathrm{lb}$., at 46 .

${ }^{85}$ See Charles Taylor, Sources of the Self: The Making of Modern Identity, (Cambridge: Cambridge University Press, 1989).

${ }^{86}$ See Charles Taylor, "The Politics of Recognition," in Amy Gutmann (Ed), Multiculturalism: Examining the Politics of Recognition, (Princeton: Princeton University Press, 1994) 25 who follows the Hegelian dialectic of the master and the slave: the slave would not be so called without the master and vice versa. The identity of one rests on the existence of the other, or through their mutual recognition of one another, as one becomes a subject by the recognition of another subject. 
surrounding the wearing of a veil (especially with regard to Cowan's arguments in relation to Articles 8 and 9).

Without a critical legal pluralist approach "[l]egal subjects...[are] subsumed under one (or even several) homogenous labels instead of being allowed to persist as heterogeneous, multiple creatures" ${ }^{87}$ The Begum case illustrates one way in which the argument about veiling might be presented: as one of human rights. The right to manifest one's religion under Article 9 of the Convention is relied upon as one way to view the wearing of the veil is as a religious obligation. However, the legacy of Begum is that claims of religious dress under the provisions of Article 9 will no longer be successful. As previously stated, legal scholars suggest alternative rights-based approaches for the success of claims related to religious dress (e.g. right to private and family under Article 8 of the Convention). The disadvantage of a rights-based approach, however, is that it requires the practice of veiling to be labelled in terms of being either a religious; cultural; or private practice; and its denial may infringe the right to education. An amalgamation of several human rights categories may still not fully capture the multi-faceted nature of Muslim women's experience of the veil: the practice of veiling may not fit neatly into human rights law. For example, Azizah Al-Hibri illustrates the complicated relationship between particular interpretations of Islamic religion and specific Muslim cultures. ${ }^{88}$ She argues that the nuances between religion and culture may be clear to an insider, but appear interchangeable to an outsider. The relationship between culture and religion is further complicated for first, second, and beyond generations of immigrants who may create themselves a hybrid identity which interweaves two (or more) very different cultures. The advantage of Kleinhans and Macdonald's critical legal pluralist approach is that it does not appeal to an 'essential' or 'anthropomorphic' individual of modern human rights treaties; rather to the way the modern self perceives itself to be individualistic. ${ }^{89}$

A critical legal pluralist analysis of Begum overcomes the critiques of legal pluralism whilst retaining a pluralistic approach and defying monolithic subjects and laws. Griffiths' legal pluralist approach may illuminate the operation, interaction and conflict of multiple normative orders, but it also undermines the rule of law, perpetuates an institutional notion of law, and essentialises normative orders and communities. Kleinhans and Macdonald's critical legal pluralist approach overcomes these criticisms by arguing that the definition of law is generated in the imaginations of legal subjects. As previously stated, it was claimed in Begum, and in the media, that Begum found the wearing of the jilbab obligatory for Muslim women: from a critical legal pluralist perspective, Begum was following the law. A critical legal pluralist approach

\footnotetext{
${ }^{87}$ Kleinhans and Macdonald, supra note 75, at 36.

${ }^{88}$ Azizah. Y. Al-Hibri, “Is Western Patriarchal Feminism Good for Third/World Minority Women?" in Sussn Moller Okin et al. (Eds), Is Multiculturalism Bad for Women? Susan Okin Miller with Respondents, (Princeton: Princeton University Press, 1999) 41.

${ }^{89}$ Kleinhans and Macdonald, supra note 75, at 42.
} 
highlights the circularity of the relationship between law and legal subject as Begum, and others, view the practice as legal and by regulating her behaviour, she demonstrates this legality. A legal subject's understanding of his/her own individuality exposes the inadequacy of human rights categories in this situation. A critical legal pluralist analysis is achieved by questioning what legal subjects view as law, what they view to be binding in their everyday lives. This subjective approach is crucial to the legal interpretation of Muslim women wearing the Islamic veil.

\section{CONCLUSIONS}

The Begum case illustrates that state school uniform policies in England do not have to accommodate a pupil's requirements to wear religious dress. The House of Lords held that there was no infringement with a pupil's right under Article 9 of the Convention if they could attend another school which accommodated their religious beliefs and that there was also no infringement of Article 2 of the First Protocol. Even in a situation where a pupil is not able to attend another school which accommodates the religious dress in its policy, an infringement of the right to manifest religion is justified if a multi-cultural and multi-faith school has proportionate and legitimate aims, such as protecting the rights and freedoms of other pupils. The $X v Y$ School and Watkins-Singh cases both illustrate that Begum has come to mean that claims related to state schools accommodating religious dress will not be successful under the provisions of Articles 9 and 2 of the First Protocol.

Begum raised a contentious issue illustrated by the various reasoning used to buttress judgments and various comments of the case provided by scholars. For example, even though the jurisprudence of the European Court of Human Rights (in the Hasan and Chanaush cases) determines that national courts should not consider the validity of a claimant's subjective beliefs, a court may in exceptional circumstances. It is contended that the various assumptions surrounding the reasons women wear the veil create an exceptional circumstance whereby consideration of a legal subject's subjective belief is central to the issue. Writing in the majority, Lord Bingham stated that although Article 9(1) of the Convention was "engaged and applicable", as Begum sincerely held the religious belief she professed; however, he stated that, rather than a manifestation, her actions were merely motivated or inspired by her beliefs. Idriss argues that the majority judgment by the House of Lords is the correct reasoning as it upholds the discretion of schools to decide their own uniform policies. He supports the presence of an objective element in relation to subjective beliefs which, incidentally, confirms the approach of the Court of Appeal (which referred to the European Court of Human Rights decision in the Kokkinakis case) and allowed Begum her appeal. However, the Court of Appeal decided that the Begum did not create an exceptional circumstance in order to consider Begum's subjective beliefs.

Hill and Sandberg critique the House of Lords' judgment because of the universal application of the specific situation rule and the impossibility test (established by the in the European Court of Human Rights in the Kalaç and Jewish Liturgical Association cases). The House of Lords did not 
explain how their interpretation of European jurisprudence (that there is no infringement where an individual voluntarily accepts employment (or a similar role) and there are other means open to a claimant, without causing them undue hardship) correlates with the statutory duty to provide education to children. It would have been simpler for the House of Lords to follow the reasoning of Bennett J, sitting in the High Court decision of the case, and state that Begum's actions were merely motivated by her beliefs and therefore her right to manifest her religion was not infringed.

Although Hill and Sandberg support a subjective approach to be taken in relation to religious belief like that originally put forward by Scarman $L$ (in the Ahmad case) and Lord Nicholls (in the Williamson case), they also argue that the minority opinion of Baroness Hale and Lord Nicholls in Begum (that Begum's right to manifest her religion was infringed under Article 1, but this infringement was justified in order to protect the rights of others under Article 9(2)) is the correct legal approach as it follows the more recent jurisprudence of the European Court of Human Rights (in the Sahin case).

Davis acknowledges the importance of protecting a legal subject's subjective belief and accurately questions whose belief is under discussion in the Begum case, as both the majority and minority decisions of the House of Lords placed importance on protecting of the rights of others or the influence of others in relation to the practice of veiling. Baroness Hale was therefore right to consider Begum's subjective beliefs. However, although Baroness Hale referred to a multitude of scholarly opinions in relation to the practise of veiling she did not consider Begum's narrative account of her beliefs and because of Begum's young age, Baroness Hale agreed with the decision of the majority not to allow the appeal. The result of the Begum case is that provided the right to manifest religion can be exercised elsewhere then there is no infringement.

Arguably, the essence of Denbigh High School's uniform policy was to accommodate the religious and cultural diversity of the wider community, and to this end, girls were also allowed to wear a shalwar kameeze and hijabs which identifies the wearers as following particular religious rules or having a particular heritage. In agreement with Booth it would have made little difference to allow Begum to wear a jilbab. School uniform policies can only stipulate a general standard of dress as pupils inevitably wear their own interpretations of school uniforms, due to the latest fashions and their economic backgrounds.

Begum was not prevented from wearing a jilbab by the various Court decisions of her case, she simply attended another school where she could continue to wear the veil. I contend that simply ignoring religious or informal law, by transferring it to another place (usually out of sight), does not mean it no longer exists (or is out of mind). The advantage of a legal pluralist analysis of Begum is that this approach exposes the operation, interaction and conflicts of normative orders. It provides an opportunity for equal focus to be given to Court judgments of 
the case as well as the normative ordering of the Muslim community in Luton, as reflected in the uniform policy of Denbigh High school. A legal pluralist approach documents the interactions between these normative orders, such as: the incorporation of the state schools self-regulation of uniform policies into state-law; and, the conflict between the majority and minority views of Islamic scholars as to the appropriate level of dress for Muslim women.

A critical legal pluralist analysis of Begum has not been previously put forward. It is advantageous as it overcomes the critiques of legal pluralist analysis and it elucidates a perspective that both a traditional legal pluralist and a doctrinal approach occlude. The practice of veiling is no longer confined to the essentialist human rights categories of religion, or culture, or privacy, or ramifications for a woman's education (or an amalgamation of such categories), rather it is given the potency of law (or a legal obligation) equal to that of state-law. It may be argued that this approach undermines the value of state-law, as a variety of interpretations are deemed to be equally valid. However, the various decisions of Begum, which all follow different legal reasoning, illustrate that there can be multiple interpretations of the same law. A critical legal pluralist approach determines that in some situations perspectives of law can be expanded, enriched and enhanced.

However, a critical legal pluralist analysis of Begum may perpetuate assumptions in relation to a legal subject's perspective of law: as what a legal subject views as law can only be assumed. Overcoming these assumptions entails actually asking Muslim women the critical legal pluralist question in order to expose the multiple beliefs and reasons for wearing the veil which exist, and which are often ignored. This requires utilising critical legal pluralism as a legal methodology, rather than a legal analysis. Nevertheless, a presupposition of critical legal pluralism is that law is formed in the imagination of a legal subject. What if Muslim women who wear the veil do not think in normative terms? I suggest that the limits of this approach can only be tested by utilising the critical legal pluralism as a legal methodology, which requires further empirical work to be undertaken in this interesting area of law. 